\title{
Molecular Characterization of Deformed Wing Viruses Identified in Honeybee (Apis mellifera L.) Colonies in Erzincan Province of Turkey
}

\author{
Abdullah Güller ${ }^{*}$, Mustafa Usta ${ }^{2}$, Gözdenur Çakar ${ }^{3}$, Zeynelabidin Kurt $^{4}$
}

\begin{abstract}
1** Bingol University, Faculty of Agriculture, Department of Plant Protection, Bingöl, Turkey, (ORCID: 0000-0003-3887-4208), aguller@bingol.edu.tr ${ }^{2}$ Van Yüzüncü Yıl University, Faculty of Agriculture, Department of Plant Protection, Van, Turkey, (ORCID: 0000-0002-3940-2774), mustafausta@ yyu.edu.tr ${ }^{3}$ Bingol University, Institute of Science and Technology, Department of Bee and Bee Products, Bingöl, Turkey, (ORCID: 0000-0003-3887-4208), gozdenurcakar@gmail.com

${ }^{4}$ Bingol University, Institute of Science and Technology, Department of Bee and Bee Products, Bingöl, Turkey, (ORCID: 0000-0002-3371-964X), abidinkurt21@icloud.com
\end{abstract}

(İlk Geliş Tarihi 11 Haziran 2021 ve Kabul Tarihi 21 Ağustos 2021)

(DOI: $10.31590 /$ ejosat.951040)

ATIF/REFERENCE: Güller, A., Usta, M., Çakar, G. \& Kurt, Z. (2021). Molecular characterization of Deformed wing virus identified in honeybees (Apis mellifera L.) colonies in Erzincan province of Turkey. European Journal of Science and Technology, (27), 186-192.

\begin{abstract}
Deformed wing virus (DWV), which belongs to the Iflaviridae family, is a devastating virus causing severe financial losses in honey bee colonies all over the world. In 2020 (November), virus-suspected honey bee specimens collected from Erzincan province were screened by molecular assays against DWV infection. In 6 of 12 samples, an expected approximately 700 bp DNA bands were achieved, indicating probably virus-positive. Two randomly selected amplified DNA band suggesting the presence of the virus was further cloned into a pGEM-T Easy vector and electrically transformed into E. coli competent bacteria. Recombinant plasmids obtained from cloning were purified from E. coli and sequenced by next-generation sequencing (NGS). The partial nucleotide sequences of DWV were ascertained to contain 711 nucleotides and these sequences were recorded in the NCBI GenBank with MW962981 and MW962982 accession number. The highest sequence similarity of both isolates ranged from $98.03 \%$ to $98.17 \%$, at the nucleotide level. Furthermore, phylogenetic relationships of Erzincan DWV sequences were revealed using 15 unique sequences from different ecological regions registered in the GenBank. Phylogenetic tree displayed that DWV Erzincan isolates are clustered with UK (HM067438), Spain (MK262743), and Sweden (MN746311) isolates. According to our best knowledge, DWV has been reported for the first time in the honey bees from Erzincan province of Turkey by this study.
\end{abstract}

Keywords: Deformed wing virus, honey bee, RT-PCR, cloning, sequence.

\section{Erzincan İlinde Bal Arısı (Apis mellifera L.) Kolonilerinde Tespit Edilen Deforme Kanat Virüsünün Moleküler Karakterizasyonu}

$\ddot{O} z$

Iflaviridae ailesine ait olan deforme kanat virüsü (DWV), tüm dünyada bal arısı kolonilerinde ciddi maddi kayıplara neden olan yıkıcı bir virüstür. 2020'de (Kasım) Erzincan ilinden toplanan virüs şüphesi olan bal arısı örnekleri, DWV enfeksiyonuna karşı moleküler testlerle tarandı. Test edilen 12 örneğin 6'sında muhtemel virüs varlığını gösteren yaklaşık 700 bp DNA bandı elde edildi. Virüsün varlığını gösteren bantlardan rastgele seçilen iki amplifiye edilmiş DNA bandı pGEM-T Easy vektörüne klonlanmış ve elektriksel olarak kompetan E. coli bakterisine aktarılmıştır. Klonlamadan elde edilen rekombinant plazmitler, E. coli'den saflaştırılmış ve yeni nesil dizileme (NGS) ile dizilenmiştir. DWV'nin kısmi nükleotid dizilerinin 711 nükleotid içerdiği tespit edilmiş ve bu diziler MW962981 ve MW962982 erişim numarası ile NCBI GenBank'a kaydedilmiştir. Her iki izolatın en yüksek dizi benzerliği, nükleotid düzeyinde \%98.03 ile \%98.17 arasında değişmiş̧ir. Ayrıca, Erzincan DWV dizilerinin filogenetik ilişkileri, GenBank'ta kayıtlı farklı ekolojik bölgelerden 15 benzersiz dizi kullanılarak ortaya çıkarılmıştır. Filogenetik ağaç, DWV Erzincan izolatlarının İngiltere (HM067438), İspanya (MK262743) ve İsveç (MN746311) izolatları ile kümelendiğini göstermiştir. Literatür bilgilerimize göre, bu çalışma ile DWV (Deforme kanat virüsü) Türkiye'nin Erzincan ili bal arılarında ilk kez rapor edilmiş̧ir.

Anahtar Kelimeler: Deforme kanat virüsü, bal arısı, RT-PCR, klonlama, sekans. 


\section{Introduction}

Beekeeping is an agricultural activity that produces bee products such as honey, royal jelly, pollen, beeswax, propolis, and bee venom, as well as living materials such as queen bees and swarms. Honey bees, the leading actors in this industry, are socially trainable pollinator insects that also serve the future of the world (Bingöl \& Erkan 2014; Hung et al., 2018). Various diseases and pests have a negative impact on honey bee health. Especially in devastating situations such as colony collapse disorder (CCD), which is the current common problem, the role of honeybee viruses is inevitable and cannot be ignored. Until the late 1980s, honey bee viral infections were ignored and believed to be generally harmless worldwide. Currently, 18 of the viruses infecting honey bees in both the brood and adult stages have been described in detail in all country, the most common of which are DWV (Deformed wing virus), ABPV (Acute bee paralysis virus), CBPV (Chronic bee paralysis virus), KBV (Kashmir bee virus), BQCV (Black queen cell virus), and SBV (Sacbrood virus) (Genersch \& Aubert, 2010; Doganay \& Girisgin, 2017).

DWV, which belongs to the Iflavirus genus, was first isolated from adult bees in Japan and spread to many parts of the world. The viral pathogen, whose natural hosts are A. mellifera and A. cerana, is virion $30 \mathrm{~nm}$ in diameter cubic symmetry containing (+) ssRNA genome (Lanzi et al., 2006; Maramorosch \& Shatkin, 2007). To initiate infection, the viral load and virulence of DWV are crucial. The causative agent needs approximately 4 times more viral load than healthy ones. The incidence of DWV disease depends on seasonal fluctuation and typically increases in egg, adults, and pupae development stage from summer to autumn (Tentcheva et al., 2004; Yue et al., 2007). In infected adult bees, wrinkled and deformed wings are observed primarily, and shrinkage body and general colorless are noticeable secondarily. Although DWV rarely causes death in honey bee pupae, the average life expectancy of virus-infected adult bees is shorter than healthy ones (Maramorosch \& Shatkin, 2007). The viral pathogen has been detected in honey bees' digestive system, semen, testicular epithelium, feces, and even fat cells responsible for many metabolic and endocrine functions as well as the synthesis of antimicrobial peptides. Infected adipose tissue is the main cause of physiological disorders, poor development of queen eggs, and suppression of the immune system (Fievet et al., 2006; Chen et al., 2006).

Many studies of honey bee viruses indicate that this virus is the most frequently detected bee virus worldwide (Cirkovic et al., 2018; Roberts et al., 2017; Rüstemoğlu \& Sipahioğlu, 2016). The destructive virus is transmitted to the new host vertically from the queen bee to its egg and horizontally through food and feeding. On the other hand, Varroa destructor, the ectoparasitic mite, serves as a biological vector of DWV. The positive correlation between both suggests that both factors play an important role in CCD, which is the critical issue of recent years (Barroso-Arévalo et al., 2019; Schöning et al., 2012; ReyesQuintana et al., 2019). Virus infections should be closely monitored to ensure the continuity of honey bee colonies. To prevent possible colony losses, serological and molecular-based techniques are of vital importance in determining the DWV particle in a short time (Martin et al., 2013; Abd-El-Samie et al., 2021).
In this study, we searched the presence of DWV in the honey bee colony associated with virus symptoms in Erzincan province of Turkey. Also, we investigated the phylogenetic relationship of the identified viral pathogen based on the relevant gene region.

\section{Material and Method}

\subsection{Biological Material}

This study was carried out with the honey bees collected from the apiary in Erzincan province in November 2020. A total of 12 worker bee samples with and without viral symptoms were collected from only one apiary during randomly visited hive inspections. The samples were brought to Bingöl University Phytopathology Laboratory and stored at $-80^{\circ} \mathrm{C}$ until use.

\subsection{Extraction of TNA from collected honey bees}

In order TNA extraction from all samples showing typical viral symptoms and symptomless, silica-based method was used as declared by Foissac et al., (2001) A total of 12 groups, each group containing three honey bee samples were subjected to TNA isolation. Briefly, samples were crushed in $1 \mathrm{ml}$ of grinding buffer containing 2-mercaptoethanol (ME), and about $500 \mu \mathrm{l}$ suspension was poured into Eppendorf tube $(1.5 \mathrm{ml})$ and added $100 \mu \mathrm{l}$ sarkosyl $(10 \%)$. The mixture was kept at $70{ }^{\circ} \mathrm{C}$ for 15 min and then kept on ice for $5 \mathrm{~min}$, then centrifuged at 13000 $\mathrm{rpm}$ for $10 \mathrm{~min}$. The upper phase was transferred to the mixture containing EtOH $(150 \mu \mathrm{l}), \mathrm{NaI}(6 \mathrm{M}, 300 \mu \mathrm{l})$, and resuspended silica $(30 \mu \mathrm{l})$, incubated for 10 minutes on an intermittent shaker and then centrifuged at $6000 \mathrm{rpm}$. The upper liquid was discarded, the bottom pellet was dissolved by adding $500 \mu \mathrm{l}$ of washing buffer, and then centrifuged at $6000 \mathrm{rpm}$ for $1 \mathrm{~min}$. The washing step was repeated. The pellet resuspended in $150 \mu 1$ nuclease-free water was kept at $70^{\circ} \mathrm{C}$ for 4 min and centrifuged at $13000 \mathrm{rpm}$ for $3 \mathrm{~min}$. Finally, the supernatant was transferred to a sterile tube and stored at $-20^{\circ} \mathrm{C}$ for further steps.

\subsection{Complementary DNA synthesis and PCR Method for DWV detection}

For the reverse transcription step, reaction mix containing 5 $\mathrm{ml}$ of extracted TNA and nuclease-free water, $1 \mu \mathrm{ldNTP}$ mix (10 $\mathrm{mM})$, and $1 \mu \mathrm{l}$ random hexamer primer $(50 \mathrm{pmol} / \mu \mathrm{l})$ were kept at $65{ }^{\circ} \mathrm{C}$ for $5 \mathrm{~min}$. The reaction mix obtained was added to the previously prepared mixture containing $2 \mu \mathrm{l}$ DTT $(0.1 \mathrm{M}), 4 \mu \mathrm{l}$ 5X RT reaction buffer, $1 \mu \mathrm{l}$ RNase inhibitor, and $1 \mu \mathrm{l}$ RT enzyme (Thermo Scientific, Vilnius, Lithuania) and incubated first at 42 ${ }^{\circ} \mathrm{C}$ for $50 \mathrm{~min}$, then at $70{ }^{\circ} \mathrm{C}$ for $15 \mathrm{~min}$ to stop the reaction. $2 \mu \mathrm{l}$ of the synthesized cDNA was used as a template for PCR tests.

To perform PCR testing, primers that were reported by Chen et al., (2004) based on the sequence of the partial RdRp gene of the viral agent were used. Approximately $700 \mathrm{bp}$ of amplification product is expected from DWV-F- 5'ATCAGCGCTTAGTGGAGGAA $-3^{\prime}$ and DWV- R- 5'TCGACAATTTTCGGACATCA-3' primers. The $50 \mu$ reaction mixture consisted of $4 \mu \mathrm{L}$ cDNA, $0.4 \mu \mathrm{l}$ Taq enzyme $(5 \mathrm{U} / \mu \mathrm{l})$ (Thermo, USA), $34.6 \mu \mathrm{l}$ nuclease-free water, $5 \mu \mathrm{l} 10 \mathrm{X}$ PCR Buffer, $3 \mu \mathrm{l} \mathrm{MgCl} 2(25 \mathrm{mM}), 1 \mu \mathrm{ldNTP}(10 \mathrm{mM})$, and $1 \mu \mathrm{l}$ of each primer $(20 \mu \mathrm{M})$. PCR cycles were implemented as 35 cycles at $95^{\circ} \mathrm{C}$ for $30 \mathrm{sec}, 55^{\circ} \mathrm{C}$ for $1 \mathrm{~min}$, and $68^{\circ} \mathrm{C}$ for $2 \mathrm{~min}$, a final extension of $68^{\circ} \mathrm{C}$ for $5 \mathrm{~min}$. PCR assays were carried out on Eppendorf Mastercycler (Hamburg, Germany). In this study, an isolate determined to be DWV as a result of sequencing was 
used as a positive control in all studies. cDNA obtained from healthy bees was used as a negative control. $15 \mu \mathrm{l}$ of PCR yields and $1 \mathrm{~kb}$ DNA ladder (Fermentas, Lithuania) were loaded in 1\% agarose gel wells, electrophoresed, visualized under UV light, and photographed.

\subsection{Cloning, Sequencing and Phylogenetic relationships}

For cloning, two DWV-positive bands purified from the agarose gel were directly inserted in bacterial cloning vector (pGEM T- Easy) (Promega, USA) using T4 DNA ligase enzyme, then transformed into E. coli competent cell strain JM109, separately. After that, recombinant DNA was isolated from the liquid culture formed from white-colored bacterial colonies indicating the presence of cloning, and send to sequencing (Sentebiolab/Ankara/Turkey). Sequences obtained were submitted to NCBI (National Center for Biotechnology Information). Nucleotide similarity analysis of DWV isolates obtained from Erzincan honey bees was implemented with the BLASTn at NCBI online program. Alignment analysis and phylogenetic relationship were performed utilizing the CLC Main Workbench software program (QIAGEN, Version 6.7.1). The phylogenetic tree was created using fifteen same isolates from different origins published in the GenBank (Table 1).

Table 1. Chart showing information on DWV isolates taken from NCBI used for phylogenetic tree in present study

\begin{tabular}{llllll}
\hline No & Acc. No. & Country & Isolate & Host & Isolation source \\
\hline 1 & HM067438 & UK & VDV-1-DWV-No-9 & A. mellifera & - \\
2 & MK262743 & Spain & DWV type A & A. mellifera & - \\
3 & MN746311 & Sweden & VIVA-b2b & A. mellifera & pupae, adult \\
4 & MT747987 & Italy & DWV-B/A/2018/ITA & A. mellifera & - \\
5 & KX783225 & Belgium & leuven-dwv1 & A. mellifera & - \\
6 & MF036686 & China & 2C1 & A.mellifera & pupae \\
7 & KY909333 & Italy & Vespa_crabro_DWV_PI_2016 & Vespa crabro & abdomen \\
8 & MG831200 & USA & Maryland/2015/304 & A. mellifera & - \\
9 & AY292384 & Italy & PA & A. mellifera & - \\
10 & MT096518 & Spain & FTA1-4 & - & - \\
11 & AJ489744 & Italy & - & A. mellifera & \\
12 & KU847397 & Austria & Austria 1414 & A. mellifera & pupae \\
13 & KJ437447 & UK & Varroa-infested-colony-DJE202 & A. mellifera & - \\
14 & MN538209 & Netherlands & DWV_B_Netherlands & A. mellifera & - \\
15 & AF183905 & S. Africa & South African & A. mellifera & \\
\hline
\end{tabular}

\section{Results and Discussion}

With 7.4 million colonies, Turkey has apiculture potential globally, following China and India (Doganay \& Girisgin, 2017). Until now, the beekeeping industry has been threatened by abiotic factors and biotic infectious agents such as bacteria, viruses, microsporidia, fungi, and parasites causing colony losses in honey bees (Cox-Foster et al., 2007; Francis et al., 2013; Genersch et al., 2010). Among honey bee pathogens, viral agents have an important share in bee and bee products both in terms of the labor force and economic loss. DWV, responsible for the decline of the honey bee population, is the most familiar virus globally and usually causes latent infections that cannot be perceived by beekeepers, and infection is inevitable when viral titer reaches the level of infection. In the case of DWV infestation, characteristic symptoms such as weakness, split and deformed wings, and creep behavior occur in diseased honeybees (Gülmez et al., 2009; Rüstemoğlu \& Sipahioğlu; 2019). Its presence has been reported so far in many countries, including Serbia, Sweden, Australia, Chile, UK, Japan, and Bulgaria (Bailey \& Ball, 1991; Rodríguez et al., 2014; Cirkovic et al., 2018; Locke et al.. 2017; Roberts et al., 2017; Ryabov et al., 2016; Shumkova et al., 2018).

In this study, we sampled a total of 12 worker bees including honey bee showing deformed and vestigial wings, shrunk abdomen size, and darkened whole-body from one of the apiaries visited upon complaints from beekeepers in autumn 2020 in Erzincan province of Turkey (Fig 1). 


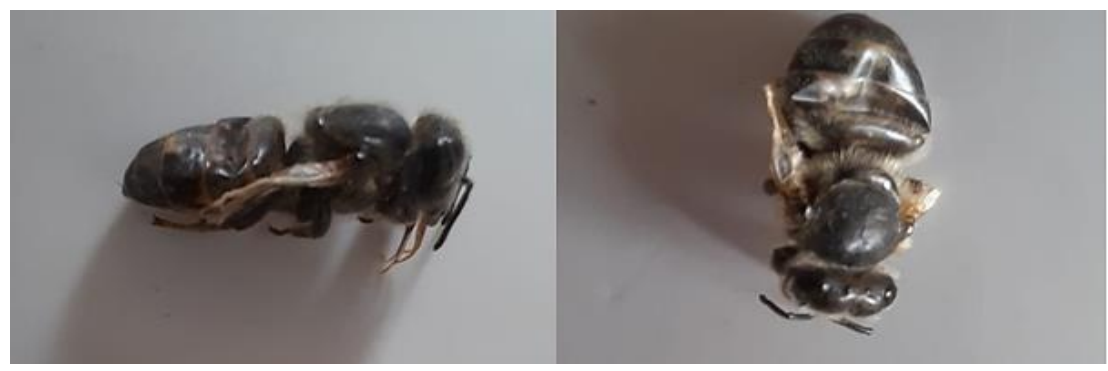

Figure 1. Deformed wing virus specific symptoms in worker honey bees collected from Erzincan province

Collected samples were molecularly analyzed to determine the presence of the Deformed wing virus (DWV). Following cDNA synthesis, the RT-PCR test amplified an approximately $700 \mathrm{bp}$ long DNA fragment of the helicase gene of the associated agent in agarose gel (Fig 2). As a result of cloning and sequencing of two randomly selected PCR yields, it was determined that the amplified fragment contained 711 nucleotides. BLASTn analysis revealed that the Erzincan viral sequences were closely related to the helicase region of the polyprotein gene of DWV, with a high nucleotide identity ranging from $98.03 \%$ to $98.17 \%$. The sequences obtained were registered in the GenBank (Acc. Nos: MW962981 and MW962982).

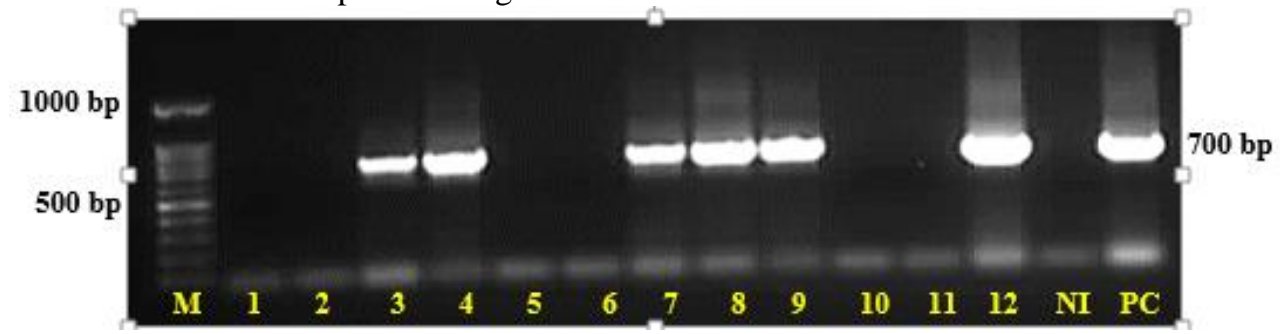

Figure 2. Agarose gel pattern showing DNA fragment of DWV from whole body samples tested by RT-PCR using DWV-specific primer sets. Lane M: $1 \mathrm{~Kb}$ DNA marker Lane 3-4-7-8-9-12: DWV-infected honeybees, NI: No Infection, PC: DWV-positive control.

Mixed infections of DWV and other prevalent honey bee viruses have been extensively reported in studies conducted worldwide. Although we tested other common pathogens (ABPV, CBPV, BQCV, and SBV) molecularly, we could only detect this virus in present study. This picture probably arose because honey bee samples were not transported in the cold chain to the laboratory where they will be tested.
Based on pairwise comparisons employed the CLC Main Workbench software, both DWV sequences (MW962981 and MW962982) exhibited 97.19\% nucleotide homology between themselves. Turkish-Erzincan DWV isolates were aligned with other DWV isolates from different countries in NCBI GenBank and the phylogenetic dendrogram was constructed (Fig 3).

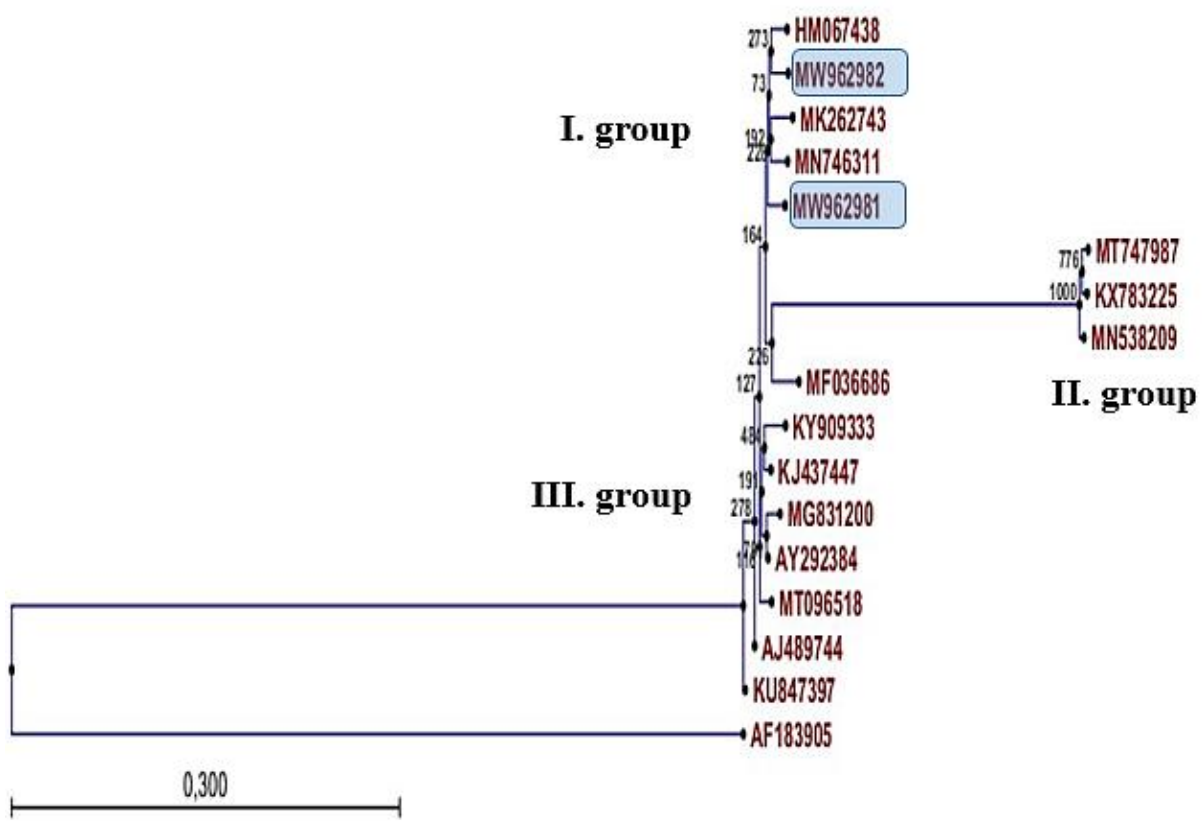

Figure 3. Phylogenetic dendrogram generated using Neighbor-joining algorithm of polyprotein gene sequences of DWV. New sequences from Erzincan province and other sequences are pointed out with "blue filled circle" and the Acc. Nos, respectively. The Black queen cell virus (BQCV) (AF183905) is included as an outgroup from South Africa. 
The phylogenetic tree consisted of three main clusters based on nucleic acid sequence similarity. Our isolates (MW962981 and MW962982) were in the first group together with the UK, Spain, and Sweden isolates of DWV from A. mellifera honey bee. A remarkable point in the phylogenetic tree is that the second group was clearly in a cluster completely separate from the cluster with other DWV isolates. This separate cluster most likely resulted from the presence of different variants of DWV such as DWV-A, DWV-B (also recognized as Varroa destructor virus-1), and DWV-C, as stated by Posada-Florez et al., (2019).

In line with former studies, DWV, one of the deadly viruses parasitizing honey bees, has been well-studied in various geographic regions of the world and in Turkey (Ribière et al., 2008; Cepero et al., 2014; Barroso-Arévalo et al., 2019). The occurrence of DWV was first detected in 2006 in the Eastern Mediterranean region, where heavy colony losses were experienced, and it was officially identified in 2008 and DWV infection was detected in all studied colonies (Muz \& Muz, 2008). Apart from this, many studies conducted in different regions of Turkey have focused on honey bee viruses. As previously stated, the DWV genome is large and primers generating different amplicons based on different gene regions of the associated virus can be used for accurate viral diagnosis in A. mellifera by many researchers. In the study conducted by screening 15 apiaries in the Burdur province, DWV, ABPV, and BQCV were detected in 13 apiaries. Unlike our study, 618 bp amplicon was obtained using primers specific to the RNA helicase gene region of DWV. Also, 98\% nucleotide sequence similarity was determined between the two isolates characterized (Cagirgan et al., 2020). In Hatay and Tekirdağ province, queens and worker bees collected from separate colonies were analyzed against DWV by RT-PCR using primer pair reported by Berenyi et al. (2006). DWV infection was determined at a high rate and $434 \mathrm{bp}$ amplicon encoding the helicase enzyme gene was obtained (Muz \& Muz, 2009; 2017). The presence of DWV was investigated by RT-PCR using primers to specific polyprotein gene in worker, drone honey bees, and the varroa mite in Ordu province. The test results of Gülmez et al., (2009) were resulted in 395 bp DNA fragments, indicating the viral pathogen presence. Using the same primer set, similar results were obtained by Karapinar et al., (2018) who tested 260 adult honey bees from 26 apiaries in the province of Van. In this study, DWV and BQCV viral infections were detected at $69.23 \%$ and $88.46 \%$, respectively, but ABPV and CBPV could not be found in honey bees collected.

Although DWV is primarily one of the important hosts for honey bees, it can also host insects such as ants (Messor concolor). Ant samples collected from Şırnak and Hakkari provinces were tested for DWV and BQCV. In this study, $488 \mathrm{bp}$ DNA fragments for the DWV-RdRP gene (RNA-depended RNA polymerase) and $568 \mathrm{bp}$ for BQCV- partial CP gene (capsid protein gene) were obtained using genome-specific primers (Rüstemoğlu, 2020). In another comprehensive survey conducted in Hakkari, single and mixed infections combined with BQCV, SBV, and CBPV of DWV were identified in worker bees collected from 90 apiaries (Rüstemoğlu \& Sipahioğlu, 2019). Rüstemoğlu, (2019) also reported the DWV in honey bees, detected in 9 out of a total of 24 bees, from Şanliurfa, Diyarbakır, Mardin, Siirt, and Şırnak provinces using the qRTPCR test, with an infection rate of $37.75 \%$. Kalayci et al., (2020) reported six virus DWV, the most widespread virus in $44.7 \%$, $\mathrm{ABPV}$ in $35.5 \%, \mathrm{BQCV}$ in $28.9 \%$, $\mathrm{SBV}$ in $22.3 \%$, $\mathrm{CBPV}$ in
$18.4 \%$, and IAPV in $6.5 \%$ of samples collected from 76 apiaries from Bursa, Kütahya, Manisa, İzmir, Aydın, Muğla, and Adana with complaints of the declining colony that (Kalayci et al., 2020).

Honey bee viruses, which have serious side effects in honey bee colonies, can exist at the colony level or individually as single or mixed infections. Cagirgan \& Yazici, (2021) developed the multiplex PCR method, which is critical for honey bee infectious diseases and has the potential to simultaneously detect more than one virus. In this practical, advantageous, and timesaving method, reference primers that are compatible with each other adopted by distinct honey bee viral disease researchers were used. A total of 60 samples consisting of 30 adults and 30 larvae collected from 111 apiaries in Kütahya, Manisa, Uşak, İzmir, Denizli, Aydın, and Muğla provinces were tested against common five honey bee viruses using the multiplex PCR method. All viral agents (DWV, BQCV, ABPV, SBV, and CBPV) were detected successfully, with the highest infection rate of DWV in the apiaries visited.

The phylogenetic tree of PCR-amplified sequences (Fig 3) indicated that the origin of Turkey-Erzincan DWV isolates has come from Europe continental, which supports the information reported by Tutkun \& Boşgelmez, (2003) that DWV has distributed from Europe to Turkey via ectoparasites varroa in 1976.

\section{Conclusions and Recommendations}

According to our literature screening, this work is the first report of the DWV infecting adult worker honey bees in the Erzincan province of Turkey. Considering the about 24 honey bee agents, a comprehensive survey study is recommended to determine the viral potential in the relevant region. In addition, the existence of any chemical treatment to eliminate viral agents makes it difficult to combat them. It is primarily transmitted by varroa and therefore Varroa and other ectoparasites must be kept under control.

\section{References}

Abd-El-Samie, EM., Basuny, NK., \& Seyam, H. (2021). Molecular characterization of viruses found in honeybee (Apis mellifera) colonies infested with Varroa destructor and Nosema cerana in Egypt. Molecular and Cellular Probes. 57: 101731 .

Bailey, L., \& Ball, BV. (1991). Honey bee pathology. Academic Press; London,United Kingdom.

Barroso-Arévalo, S., Fernández-Carrión, E., Goyache, J., Molero, F., Puerta, F., \& Sánchez-Vizcaíno, J.M. (2019). High Load of Deformed Wing Virus and Varroa destructor Infestation Are Related to Weakness of Honey Bee Colonies in Southern Spain. Front. Microbiol., 10, 1331.

Barroso-Arévalo, S., Fernández-Carrión, E., Goyache, J., Molero, F., Puerta, F., \& Sánchez-Vizcaíno, J. M. (2019). High Load of Deformed Wing Virus and Varroa destructor Infestation Are Related to Weakness of Honey Bee Colonies in Southern Spain. Frontiers in Microbiology, 10: 1331.

Berenyi, O., Bakonyi, T., Derakhshıfar, I., Koglberger, H., \& Nowotny, N. (2006). Occurrence of six honey bee viruses in diseased Austrian apiaries. Applied and Environmental Microbiology 72: 2414-2420.

Bingöl, M., \& Erkan, C. (2014). Van İli Arı Hastalıkları ve Zararlılarının Belirlenmesine Yönelik Bir Araştırma 
Yüzüncü Yıl Üniversitesi Tarım Bilimleri Dergisi. 5(2): 1420.

Cagirgan, A.A., \& Yazici, Z. (2021). The prevalence of seven crucial honeybee viruses using multiplex RT-PCR and their phylogenetic analysis. Turkish Journal of Veterinary and Animal Sciences 45(1): 44-55.

Cagirgan, A.A., Yildirim, Y., \& Usta, A. (2020). Phylogenetic analysis of deformed wing virus, black queen cell virus and acute bee paralysis viruses in Turkish honeybee colonies. Medical. Weterinary. 76 (8): 480-484.

Cepero, A., Ravoet, J., Gómez-Moracho, T., Bernal, J. L., Del Nozal, M. J., Bartolomé, C., et al. (2014). Holistic screening of collapsing honey bee colonies in Spain: a case study. BMC. Res. Notes 7:649.

Chen, Y.P., Pettis, J.S., Collins, A., \& Feldlaufer, M.F. (2006). Prevalence and transmission of honey bee viruses. Applied Environmental Microbiology, 72: 606-611.

Chen, Y.P., Smith, I.B., Collins, A.M., Pettis, J.S., \& Feldlaufer, M.F. (2004). Detection of Deformed wing virus infection in honey bees, Apis mellifera L., in the United States. American Bee Journal, 144: 557-559.

Cirkovic, D., Stevanovic, J., Glavinic, U., Aleksic, N., Djuric, S., Aleksic, J., \& Stanimirovic, Z. (2018). Honey bee viruses in Serbian colonies of different strength. Peer J. DOI: 10.7717/peerj.5887.

Cox-Foster, D.L., Conlan, S., Holme,s E.C., Palacios, G., Evans, J.D., Moran, N.A., Quan, P.L., Briese, T., Hornig, M., Geiser, D.M., Martinson, V., VanEngelsdorp, D., Kalkstein, A.L., Drysdale, A., Hui, J., Zhai, J.H., Cui, L.W., Hutchison, S.K., Simons, J.F., Egholm, M., Pettis, J.S., \& Lipkin, W.I. (2007). A metagenomic survey of microbes in honey bee colony collapse disorder. Science, 318, 283-287 DOI: $10.1126 /$ science. 1146498

Doğanay, A., \& Girişgin, A.O. (2017). Bal arisi yetiştiriciliği ürünleri hastaliklari. In: Doganay A, Aydin L (editors). 1st ed. Bursa: Dora Basın Yayın Dağıtım; pp. 21-146.

Fievet, J., Tentcheva, D., Gauthier, L., De Miranda, J., Cousserans, F., Colin, M. E., \& Bergoin, M. (2006). Localization of deformed wing virus infection in queen and drone Apis mellifera L. Virology Journal, 3:16.

Foissac, L., Gentit, P., Svanetia-Dumas, L., Dulucq, M. J., \& Candresse, T. (2001). Polyvalent detection of fruit tree tricho, capillo, and foveaviruses by nested RT-PCR using degenerated and inosine-containing primers (PDO RT-PCR). Acta Horticulturae, 550: 37-43.

Francis, R.M., Nielsen, S.L., \& Kryge, P. (2013). Varroa-Virus interaction in collapsing honey bee colonies. PLoS ONE, 8:e57540. DOI: 10.1371/ journal.pone.0057540

Genersch, E., \& Aubert, M. (2010). Emerging and re-emerging viruses of the honey bee (Apis mellifera L.). Vet. Res. 41:54 DOI: $10.1051 /$ vetres/2010027

Genersch, E., Von Der Ohe, W., Kaatz, H., Schroeder, A., Otten, C., Buchler, R., Berg, S., Ritter, W., Muhlen, W., Gisder, S., Meixner, M., Liebig, G., \& Rosenkranz, P. (2010). The German bee monitoring project: A long term study to understand periodically high winter losses of honey bee colonies. Apidologie, 41, 332-352, DOI: 10.1051/apido/2010014.

Gülmez, Y., Bursalı, A., \& Tekin, Ş. (2009). First molecular detection and characterization of deformed wing virus (DWV) in honeybees (Apis mellifera L.) and mite (Varroa destructor) in Turkey. African Journal of Biotechnology. 8 (16): 3698-3702.
Hung, K-LJ., Kingston, J.M., Albrecht, M., Holway, D.A., \& Kohn, J.R. (2018). The worldwide importance of honey bees as pollinators in natural habitats. Proc. R. Soc. B. 285: 20172140.

Kalayci, G., Cagirgan, A.A., Kaplan, M., Pekmez, K., Beyazit, A., Ozkan, B., Yesiloz, B., \& Arslan, F. (2020). The role of viral and parasitic pathogens affected by colony losses in Turkish apiaries.Kafkas Üniversitesi Veteriner Fakültesi Dergisi, 26 (5): 671-677.

Karapınar, Z., Oğuz, B., Dinçer, E., \& Öztürk, C. (2018). Phylogenetic analysis of black queen cell virus and deformed wing virus in honeybee colonies infected by mites in Van, Eastern Turkey. Medicine Weterinary. 74 (7), 460465.

Lanzi, G., De Miranda, J.R., Boniotti, M.B., Cameron, C.E., Lavazza, A., Capucci, L., Camazine, S. M., \& Rossi, C. (2006). Molecular and biological characterization of deformed wing virus of honey bees (Apis mellifera L.). Journal of Virology, 80: 4998-5009.

Locke, B., Semberg, E., Forsgren, E., \& de Miranda, J.R. (2017). Persistence of subclinical deformed wing virus infections in honeybees following Varroa mite removal and a bee population turnover. PLoS ONE. 12 (7), e0180910.

M. Ribière, Ball B.V., \& Aubert M. 2008. Natural history and geographic distribution of honey bee viruses M. Aubert, et al. (Eds.), Virology and the Honey Bee, European Communities, Luxembourg. 15-84

Maramorosch, K., \& Shatkin, A. (2007). Honey bee viruses. Advances in Virus Research. Academic Press. 33-80.

Martin, S.J., Ball, B.V., \& Carreck, N.L. (2013). The role of deformed wing virus in the initial collapse of varroa infested honey bee colonies in the UK. J. Apicult. Res. 52 251-258.

Muz, D., Muz, \& M.N. (2009). Survey of the occurrence of Deformed Wing Virus and multiple parasites of queens (Apis mellifera L.) in apiaries with collapsed colonies in Hatay, Turkey. Journal of Apicultural Research, 48(3), 204-208.

Muz, D., Muz, \& M.N. (2017). Tekirdağ'da "Koloni Kayb1 Sendromu" Benzeri Kayıp Görülen Arılıklarda Bazı Patojenlerinin Araştırılması. Kocatepe Veterinary Journal,10(1):21-28.

Muz, M.N., \& Muz, D. (2008). Occcurrence and genetic analysis of DWV (Deformed wing virus) and ABPV (Acute bee paralysis virus) and Varroa destructor-1 virus (VD-1) in Turkey. Proceedings of the 2nd Intenational Forum of Apimondia-Apiquality, Villa Mondragone, Rome, Italy. pp. 94.

Posada-Florez, F., Childers, A.K., Heerman, M.C., Egekwu, N.I., Cook, S.C., Chen, Y., Evans, J.D., \& Ryabov, E.V. (2019). Deformed wing virus type A, a major honey bee pathogen, is vectored by the mite Varroa destructor in a non-propagative manner. Scientific Reports. 9. 12445. 10.1038/s41598-01947447-3.

Reyes-Quintana, M., Espinosa-Montaño, L.G., Prieto-Merlos, D., Koleoglu, G., Petukhova, T., Correa-Benítez, A., \& Guzman-Novoa, E. (2019). Impact of Varroa destructor and deformed wing virus on emergence, cellular immunity, wing integrity and survivorship of Africanized honey bees in Mexico. Journal Invertebrate Pathology, 164: 43-48.

Roberts, J.M.K., Anderson, D.L., \& Durr, P.A. (2017). Absence of deformed wing virus and Varroa destructor in Australia provides unique perspectives on honeybee viral landscapes and colony losses. Scientific Reports, 7: 6925. 
Rodríguez, M., Vargas, M., Antúnez, K., Gerding, M., Castro FO., \& Zapata, N. (2014). Prevalence and phylogenetic analysis of honey bee viruses in the Biobío Region of Chile and their association with other honey bee pathogens. Chilean journal of agricultural research, 74(2), 170-177.

Rüstemoğlu, M. (2019). Uluslararası Arıcılık Araştırmalarıve Sürdürülebilir Kırsal Kalkınma Stratejileri Kongresi. 11-13 Ekim 2019. Bingöl, Türkiye.

Rüstemoğlu, M. (2020). Isolation and Characterization of Two Important Honeybee-Killing Virus Species, Deformed Wing Virus (DWV) and Black Queen Cell Virus (Bqcv) From Messor Concolorants (Hymenoptera: Formicidae). Applied Ecology and Environmental Research. 18. 7407-7415. 10.15666/aeer/1805_74077415.

Rüstemoğlu, M., \& Sipahioğlu, H.M. (2016) : Occurrence and molecular characterization of acute bee paralysis virus (ABPV) in honeybee (Apis mellifera) colonies in Hakkari province. Yüzüncü Yıl Üniversitesi Tarım Bilimleri Dergisi 26, 174-182.

Rüstemoğlu, M., \& Sipahioğlu, H.M. (2019). Occurrence and prevalence of six honey bee viruses in Hakkari (Turkey) and their genomic divergence. Munis Entomology \& Zoology, 14 (2): 574-583]

Ryabov, E.V., Fannon, J.M., Moore, J.D., Wood, G.R., \& Evans, D.J. (2016). The Iflaviruses Sacbrood virus and Deformed wing virus evoke different transcriptional responses in the honeybee which may facilitate their horizontal or vertical transmission. Peer J. 4: e1591.

Schöning, C., Gisder, S., Geiselhardt, S., Kretschmann, I., Bienefeld, K., Hilker, M., \& Genersch, E. (2012). Evidence for damage-dependent hygienic behaviour towards Varroa destructor parasitised brood in the western honey bee, Apis mellifera. J. Exp. Biol. 215, 264-271.

Shumkova, R., Neov, B., Sirakova, D., Georgieva, A., Gadjev, D., Teofanova, D., Radoslavov, G., Bouga, M., \& Hristov, P. (2018). Molecular detection and phylogenetic assessment of six honeybee viruses in Apis mellifera L. colonies in Bulgaria. Peer J. 2018, doi: 10.7717/peerj.5077.

Tentcheva, D., Gauthier, L., Jouve, S., Canabady-Rochelle, L., Dainat, B., Cousserants, F., Colin, M. E., Ball, B. V., \& Bergoin, M. (2004). Polymerase chain reaction detection of deformed wing virus (DWV) in Apis mellifera and Varroa destructor. Apidologie, 35: 431- 439.

Tutkun, E., \& Boşgelmez, A., (2003). Balarısı zararlıları ve hastalıkları teşhis ve tedavi yöntemleri. Bizim Büro Basımevi, Selanik Caddesi 18/11, Ankara.

Yue, C., Schroder, M., Gisder, S., \& Genersch, E. (2007). Vertical-transmission routes for deformed wing virus of honeybees (Apis mellifera). J. Gen. Virol. 88: 2329-2336. 